\title{
Hubungan dukungan-sosial yang diberikan isteri dengan konsep-diri suami yang kehilangan pekerjaan
}

Meutia Nauly*
Rippun Sihombing

\author{
Universitas Sumatera Utara
}

\begin{abstract}
ABSTRAK
Penelitian ini mengkaji peran dukungan-sosial yang diberikan istri terhadap konsep-diri suami yang kehilangan pekerjaannya. Hasil menunjukkan bahwa dukungan-sosial yang diberikan istri berhubungan positif terhadap konsep-diri suami yang kehilangan pekerjaannya. Penelitian korelasional ini mengindikasikan pentingnya dukungan-sosial yang diberikan istri dalam melindungi suami terhadap bahaya konsep-diri negatif yang diakibatkan oleh kehilangan pekerjaan.
\end{abstract}

Kata kunci: Dukungan-sosial, konsep-diri, kehilangan pekerjaan

\section{The relationships of wife social-support with husband's self-concept post experiencing job loss}

\begin{abstract}
The present study examines the role of social support provided by wife on husband's selfconcept, post experiencing job loss. The results showed that receiving social support from wife is positively related with husband's self-concept. This correlational research indicates the importance of social support provided by wife in protecting husband from the danger of negative self-concept due to job loss.
\end{abstract}

Keywords: Social support, self-concept, job loss

\footnotetext{
* Korespondensi mengenai penelitian ini dapat dilayangkan kepada Meutia Nauly melalui email: meutia@indieacademy.org
} 
Kehilangan pekerjaan dapat membahayakan fisik dan psikologis individu. Misalnya, kehilangan pekerjaan dapat menimbulkan trauma, stress, perasaan panik, marah, bingung, putus-asa, kehampaan hidup, tidak percaya diri, keraguan terhadap kemampuan yang dimiliki, mudah tersinggung, kecendrungan bunuh diri, penganiayaan anak, dan perceraian (Linn, Sandiger, Stein, 1985; Papu, 2002; Steinmetz, 1979; Voydanoff, 1987). Di dalam penelitian ini, kami berasumsi bahwa berbagai masalah tersebut muncul sebagai dampak dari konsep-diri negatif yang berkembang pada individu yang mengalami kehilangan atau pemutusan hubungan kerja. Sehubungan dengan asumsi ini, kami mencoba untuk mengeksplorasi peran dukungan-sosial isteri terhadap konsep-diri suami yang kehilangan pekerjaannya. Melalui penelitian korelasional ini, kami berharap untuk memberikan bukti ilmiah tentang pentingnya dukungan-sosial yang diberikan isteri dalam melindungi konsepdiri suami yang kehilangan pekerjaan.

\section{Konsep-diri dan kehilangan pekerjaan}

Konsep-diri merupakan persepsi seseorang mengenai dirinya, yang mencakup pengetahuan, pengharapan, dan penilaian terhadap diri (Calhoun \& Acocella, 1978; Shavelson \& Bolus, 1982; lihat juga Epstein, 1973). Dari definisi ini, konsep-diri merupakan istilah yang menaungi istilah-istilah seperti harga-diri (self-esteem: evaluasi positif/negatif terhadap diri; Kenrick, Neuberg, \& Cialdini, 2010) dan efikasi-diri (self-efficacy: evaluasi seseorang sehubungan dengan kompetensi diri dalam mencapai suatu tujuan tertentu; Omrod, 2006). Konsep-diri dapat bersifat positif atau negatif. Konsep-diri positif adalah ketika seseorang menghargai dan dapat menerima diri dengan segala kelebihan dan kekurangannya, sedangkan konsep-diri negatif adalah ketika seseorang merasa tidak berharga atau bahkan membenci dirinya sendiri (Calhoun \& Acocella, 1978).

Menurut Kozier dan Erb (1987), kehilangan pekerjaan merupakan salah satu faktor penting yang dapat membuat seseorang mengembangkan konsep-diri negatif. Konsep-diri negatif sebagai dampak dari kehilangan pekerjaan secara khusus berdampak buruk bagi seorang suami. Seorang suami pada umumnya memegang peran utama sebagai pemberi nafkah bagi keluarganya, peran ini cenderung terinternalisasi dalam konsep-dirinya (Forteza \& Prieto, 1994). Sebagai konsekuensi, kehilangan pekerjaan menimbulkan inkonsistensi antara konsep-diri yang dimiliki dengan kenyataan yang sedang dihadapi. Inkonsistensi ini mengharuskan seorang suami yang kehilangan pekerjaan untuk mengevaluasi dan mengkonstruksi kembali konsep-dirinya. Di sinilah kemungkinan munculnya pengembangan konsep-diri yang negatif. Konsep-diri negatif yang muncul akibat kehilangan pekerjaan kemudian cenderung menimbulkan kecemasan dan depresi (Feather, 1982; Kessler, Turner, \& House, 1988; Sheeran \& McCarthy, 1990; lihat juga Sheeran, Abrams, \& Orbell, 1995). Asosiasi antara konsep-diri negatif dengan kecemasan dan depresi inilah yang mungkin menjadi penyebab timbulnya berbagai masalah seperti ketidakpuasan pernikahan, bunuh diri, dan penganiayaan anak pada individu yang kehilangan pekerjaan (Beskow, 1990; Cumming \& Davies, 1994; Fincham, Beach, Harold, \& Osborne, 1997).

\section{Dukungan-sosial dan kehilangan pekerjaan}

Dukungan-sosial pada dasarnya merupakan bantuan yang diberikan oleh orang-orang terdekat (e.g., keluarga, pasangan, teman; Rice, 1987). Mengacu pada Orford (1992), bantuan yang diberikan dapat bersifat materil (e.g., menyediakan benda-benda untuk menyelesaikan masalah praktis), emosional (e.g., memberikan semangat, cinta, empati), penghargaan (e.g., menghargai usaha-usaha yang dilakukan seseorang), informatif (e.g., mengajar atau memberikan informasi suatu keahlian agar seseorang dapat menyelesaikan masalah), dan integritas sosial (e.g., menunjukkan kepada seseorang bahwa ia bagian dari kelompok yang ada untuk membantunya). Dukungan-sosial merupakan faktor penting bagi individu dalam menghadapi berbagai tekanan (Cobb, 1976; Gore, 1978; Cohen \& Syrne, 1985), termasuk 
tekanan yang diakibatkan oleh kehilangan pekerjaan. Bagi seorang suami yang kehilangan pekerjaan, istri merupakan salah satu sumber dukungan-sosial utama (Voydanoff, 1987), di mana istri berperan penting dalam memberikan kekuatan, dorongan, dan kebersamaan dalam memecahkan masalah (Gunarsa, 1994), termasuk masalah yang dihadapi suami sehubungan dengan kehilangan pekerjaannya. Misalnya, dengan adanya dukungan-sosial isteri, seorang suami cenderung mengeluarkan usaha yang lebih besar dalam mencari pekerjaan baru (Vinokur \& Caplan, 2006).

\section{Dukungan-sosial dan konsep-diri}

Dalam studi literatur yang kami lakukan, sulit sekali menemukan penelitian yang mengasosiasikan dukungan-sosial dengan konsep-diri dalam konteks kehilangan pekerjaan. Namun demikian, berbagai penelitian secara konsisten menunjukkan asosiasi dukungansosial dengan konsep-diri dalam berbagai konteks tekanan atau tantangan hidup lainnya. Misalnya, Hobfoll dan Walfisch (1984) menemukan bahwa dukungan-sosial berasosiasi secara positif dengan konsep-diri pada perempuan penderita kanker, penelitian ini juga menemukan bahwa konsep-diri dan dukungan-sosial sama-sama berasosiasi terbalik dengan depresi dan kecemasan. Siswa sekolah dengan keterbatasan kemampuan belajar (learning disability) yang mendapatkan dukungan-sosial yang adekuat juga cenderung memiliki konsep-diri yang baik (Forman, 1988). Dukungan-sosial (e.g., dari orang-tua, teman) juga berperan penting dalam pembentukan konsep-diri positif pada remaja (Hoffman, Ushpiz, \& Levy-Shiff, 1988). Singkatnya, penelitian-penelitian sebelumnya telah secara konsisten menunjukkan pentingnya dukungan-sosial sebagai faktor yang mendukung konsep-diri positif pada individu dalam menghadapi berbagai tantangan hidup. Dengan demikian, dapat diharapkan bahwa dukungan-sosial yang diberikan isteri kepada suami-pun akan dapat membantu suami dalam menjaga konsep-dirinya.

\section{Penelitian ini}

Meskipun sudah banyak penelitian yang menghubungkan dukungan-sosial dengan konsep-diri pada berbagai konteks, sepengetahuan kami, belum ada penelitian, khususnya di Indonesia yang meneliti hubungan tersebut dalam konteks kehilangan pekerjaan. Dengan demikian, di dalam penelitian korelasional ini, kami mencoba untuk memeriksa hubungan tersebut. Secara spesifik, kami memfokuskan penelitian ini pada dukungan-sosial yang diberikan isteri kepada suaminya, yang kehilangan pekerjaan. Berdasarkan penelitianpenelitian sebelumnya, yang secara konsisten menunjukkan keuntungan dukungan-sosial terhadap konsep-diri di berbagai konteks tantangan hidup, kami berhipotesis bahwa dukungan-sosial yang diberikan isteri akan berkorelasi positif dengan konsep-diri suami yang mengalami kehilangan pekerjaan. Yaitu, semakin tinggi dukungan-sosial yang diberikan oleh isteri, semakin positif konsep-diri suami yang kehilangan pekerjaannya.

\section{METODE}

\section{Partisipan}

Parsipan adalah 45 orang suami yang mengalami pemutusan hubungan kerja (i.e., kehilangan pekerjaan) berusia antara 23 sampai 38 tahun. Partisipan kami rekruit secara indicental. Mereka berpartisipasi secara sukarela, tanpa pemberian reward.

\section{Prosedur dan alat ukur}

Untuk keperluan penelitian ini, kami membuat angket yang berisi skala-skala untuk mengukur variabel-variabel penelitian. Kami menyebarkan angket ini kepada para partisipan untuk diisi. Angket kami kumpulkan setelah para partisipan menyelesaikan pengisian. Semua aitem kami buat dalam bentuk skala Likert empat titik $(1=$ sangat tidak sesuai $-4=$ sangat 
sesuai; sebagian aitem kami konstruksi secara terbalik). Konsep-diri kami ukur dengan skala yang kami konstruksi berdasarkan Calhoun dan Acocella (1978). Skala konsep-diri ini sudah mencakup ketiga aspek konsep-diri, yaitu pengetahuan (16 aitem), pengharapan (20 aitem), dan penilaian terhadap diri (18 aitem). Gabungan dari ketiga aspek konsep-diri ini membentuk satu skala dukungan-sosial yang reliabel (e.g., "Saya yakin akan sukses di masa yang akan datang", "Saya mampu melakukan pekerjaan sebagaimana orang lain dapat melakukannya"; 53 aitem; $\alpha=.98$; corrected item-to-total correlation $=.37$ sampai .88 ). Persepsi suami terhadap dukungan-sosial yang diberikan isteri kami ukur dengan skala yang juga kami konstruksi sendiri berdasarkan Orford (1992). Skala dukungan-sosial ini sudah mencakup jenis dukungan material (14 aitem), emosional (16 aitem), penghargaan (13 aitem), informatif (13 aitem), dan integritas sosial (14 aitem). Gabungan dari keenam jenis dukungan-sosial ini membentuk satu skala dukungan-sosial yang reliabel (e.g., "Isteri saya membantu saya mencari informasi lowongan kerja", Ketika pikiran saya sedang kacau, isteri saya selalu mendampingi saya"; 70 aitem; $\alpha=.98$, corrected item-to-total correlation $=.38$ sampai .90). Untuk keperluan skoring, kami menggunakan titik-tengah (mid-point) skala sebagai tolok-ukur (netral) dukungan-sosial dan konsep-diri. Dengan cara ini, konsep-diri seseorang dikategorikan cenderung negatif jika rerata skornya secara signifikan (dengan menggukanan one-sample t-test) di bawah titik-tengah, dan cenderung positif jika di atas titik-tengah tersebut. Teknik yang sama kami aplikasikan juga untuk kategori skor dukungansosial, hanya saja pelabelannya kami ganti menjadi cenderung rendah dan cenderung tinggi.

\section{HASIL}

\section{Deskriptif dan normalitas}

Dalam analisis, respon-respon setiap partisipan pada setiap aitem pada setiap skala pengukuran (Dukungan-sosial, Konsep-diri) kami reratakan sehingga menciptakan rentang skor antara 1 sampai dengan 4, senada dengan skala Likert yang kami gunakan dalam pengukuran. Rata-rata persepsi suami terhadap Dukungan-sosial yang diberikan isteri adalah $2.88(S D=0.31$, kelandaian $=-0.18$, kurtosis $=0.96)$, sedangkan rata-rata Konsep-diri suami adalah $2.79(S D=0.36$, kelandaian $=-0.55$, kurtosis $=0.67)$. Analisis one-sample t-test memperbandingkan rata-rata skor empirik dukungan-sosial, $t(44)=8.03, p=.001$, dan konsep-diri, $\mathrm{t}(44)=5.39, p=.001$, dengan titik-tengah (mid-point $=2.5$ ) skala menunjukkan hasil yang signifikan. Dengan demikian, rata-rata partisipan memiliki dukungan-sosial yang cenderung tinggi dan konsep-diri yang cenderung positif. Terakhir, analisis KolmogorovSmirnov's Test mengindikasikan distribusi skor para partisipan pada skala Dukungan-sosial, $D(45)=.13, p=.07$, dan Konsep-diri, $D(45)=.10, p=.20$, tidak berdeviasi dari normal.

\section{Dukungan-sosial isteri dan konsep-diri suami}

Kami berhipotesis bahwa dukungan-sosial yang diberikan isteri akan berkorelasi positif dengan konsep-diri suami yang mengalami kehilangan pekerjaan. Untuk menguji hipotesis ini, kami korelasikan skor total Dukungan-sosial dengan skor total Konsep-diri, dengan menggunakan korelasi Pearson. Hasil menunjukkan hubungan positif (searah) antara Dukungan-sosial dengan Konsep-diri, $r=.42, p=.002$, one-tailed test. Sesuai dengan hipotesis, hasil ini menunjukkan bahwa semakin tinggi Dukungan-sosial yang diberikan isteri, semakin positif Konsep-diri yang dimiliki oleh suami yang kehilangan pekerjaannya.

\section{DISKUSI}

Di dalam penelitian ini, kami memeriksa peran dukungan-sosial yang diberikan isteri terhadap konsep-diri suami, pasca kehilangan pekerjaannya. Hasil penelitian ini menunjukkan hubungan yang positif (searah) antara dukungan-sosial yang diberikan isteri dengan konsep-diri suami. Artinya, semakin besar dukungan-sosial yang diberikan isteri, 
semakin positif pula konsep-diri yang dikembangkan oleh suami. Dengan demikian, penelitian ini mendemonstrasikan bagaimana dukungan-sosial yang diberikan isteri merupakan hal yang sangat penting bagi kesejahteraan psikologis suami, pasca kehilangan pekerjaannya.

Sesuai dengan penelitian-penelitian sebelumnya, penelitian ini mendemonstrasikan bagaimana dukungan-sosial dapat bermanfaat bagi individu yang sedang menghadapi tekanan dalam menjalani hidupnya (e.g., Forman, 1988; Hobfoll \& Walfisch, 1984; Hoffman, Ushpiz, \& Levy-Shiff, 1988). Secara khusus, penelitian ini mendukung hasil-hasil penelitian sebelumnya tentang bagaimana dukungan-sosial berperan penting bagi individu dalam menghadapi berbagai tantangan hidup (e.g., Gore, 1978; Kasl, 1982; LaRocco, House, \& French, 1980; lihat Linn, Sandifer, \& Stein, 1985). Namun demikian, penelitian ini dapat dikatakan cukup unik karena objek eksplorasi berfokus pada bagaimana peran dukungansosial yang diberikan isteri terhadap konsep-diri suami yang kehilangan pekerjaannya di Indonesia.

Selanjutnya, kami menyadari berbagai kekurangan dari penelitian ini. Pertama, penelitian ini merupakan penelitian yang bersifat pasif korelasional, di mana kami mengukur persepsi suami sehubungan dengan dukungan-sosial yang diberikan isterinya, lalu mengkorelasikannya dengan konsep-diri sang suami. Dengan metodologi seperti ini, kami sama sekali tidak memperhatikan variabel-variabel lain yang juga berpotensi dalam menentukan konsep-diri suami, pasca kehilangan pekerjaannya. Misalnya, penelitian sebelumnya di Inggris menunjukkan bahwa dalam mengevaluasi konsep-diri, komparasi antara diri aktual (saat tidak lagi bekerja) dengan diri yang lalu (pada saat masih bekerja) merupakan prediktor stress dan penghargaan-diri (self-esteem) yang rendah pada orang-orang yang kehilangan pekerjaannya (Sheeran, Abrams, \& Orbell, 1995). Dengan demikian, akan sangat menarik di penelitian selanjutnya untuk melihat bagaimana kaitan dukungan-sosial terhadap komparasi antara diri yang lampau dengan diri aktual, dan implikasinya terhadap konsep-diri para suami yang kehilangan pekerjaannya di Indonesia.

Kedua, dalam penelitian ini, kami hanya mengasumsikan, dengan berdasarkan penemuan-penemuan di dunia barat (Eropa dan Amerika Serikat) bahwa kehilangan pekerjaan dapat menimbulkan berbagai permasalahan psikologis. Sedangkan bagaimana dampak nyata kehilangan pekerjaan terhadap kesejahteraan psikologis individu di Indonesia tidak kami sajikan. Dengan demikian, akan sangat baik jika penelitian selanjutnya tidak hanya menelaah hubungan dukungan-sosial dengan konsep-diri, akan tetapi meneliti pula implikasi dari dukungan-sosial dan konsep-diri tersebut terhadap aspek fisik dan psikologis para individu yang kehilangan pekerjaannya secara nyata. Pertanyaan yang mungkin dipertanyakan, misalnya adalah "Apakah konsep-diri sebagaimana dipengaruhi oleh dukungan-sosial dapat mengurangi stres, depresi, dan kecemasan pada orang yang kehilangan pekerjaannya?" Dengan menjawab pertanyaan seperti ini, selain dapat menunjukkan hubungan antara dukungan-sosial dengan konsep-diri, penelitian selanjutnya juga dapat menunjukkan implikasi psikologis secara nyata sehubungan dengan dampak dari kehilangan pekerjaan.

Terakhir, sebagai implikasi praktis, kami ingin mengajak para isteri yang suaminya mengalami kehilangan pekerjaan untuk melakukan dukungan-sosial yang aktif kepada suami, dengan cara-cara seperti berikut:

1. Memberikan dukungan materil dan informasi seperti menyediakan atau mengumpulkan koran, majalah, dan media lain yang memberikan informasi-informasi pekerjaan baru agar suami lebih mudah dan termotivasi untuk mencari pekerjaan baru.

2. Memberikan dukungan emosional dan penghargaan kepada suami. Seperti memberikan semangat kepada suami untuk terus mencari pekerjaan baru. Mendengar dan berempati ketika suami mengeluhkan permasalahan-permasalahan yang dihadapinya. Mencintai 
suami, meskipun untuk sementara ia tidak mampu memberikan nafkah kepada keluarga secara maksimal.

3. Terakhir, memberikan dukungan integritas sosial bagi suami. Yaitu, dengan mengajak anggota keluarga lainnya, baik itu keluarga inti (nuclear family: e.g., anak-anak) maupun keluarga-luas (extended family: e.g., saudara, ipar, mertua, ayah) untuk mendukung dan membantu suami dalam menghadapi berbagai persoalan yang diakibatkan oleh kehilangan pekerjaanya. Hal ini penting karena relasi sosial yang dimiliki anggota keluarga seringkali dapat menjadi sumber yang sangat baik bagi perolehan pekerjaan baru. Untuk dukungan bentuk ini, penting juga bagi isteri untuk mengingatkan kepada suami, bahwa keluarga akan terus mendukungnya dalam memecahkan permasalahan-permasalahan konsekuensi dari kehilangan pekerjaannya.

\section{REFERENSI}

Beskow, J. (1990). Depression and suicide. Pharmacopsychiatry, 23, 3-8. doi: 10.1055/s2007-1014522.

Calhoun, J. F., \& Acocella, J. R. (1978). Psychology of adjustment and human relationships. New York: Random House.

Cobb, S. (1976). Social support as a moderator of life stress. Psychosomatic Medicine, 38, 300-314.

Cohen, S., \& Syme, S. L. (1985). Issues in the study and application of social support. In S. Cohen, \& L. Syme (Eds.), Social support and health (pp. 3-22). San Fransisco: Academic Press.

Cummings, E. M., \& Davies, P. T. (1994). Maternal depression and child development. Journal of Child Psychology and Psychiatry, 35, 73-112.

Epstein, S. (1973). The self-concept revisited: Or a theory of a theory. American Psychologist, 28, 404-416.

Feather, N. T. (1982). Unemployment and its psychological correlates: A study of depressive symptoms, self-esteem, Protestant Ethic values, attributional style and apathy. Australian Journal of Psychology, 34, 309-323.

Fincham, F. D., Beach, S. R., Harold, G. T., \& Osborne, L. N. (1997). Marital satisfaction and depression: Different causal relationships for men and women. Psyhological Science, 8, 351-356. doi: 10.1111/j.1467-9280.1997.tb00424.x

Forman. (1988). The effects of social support and school placement on the self-concept of LD students. Learning Disability Quarterly, 11, 115.

Forteza, J. A., \& Prieto, J. M. (1994). Aging and work behavior. In H. Triandis, M. D. Dunnette, \& L. M. Hough (Eds.), Handbook of industrial and organizational psychology (2 ed., Vol. 4, pp. 446-483). CA: Consulting Psychologists Press.

Gore, S. (1978). The effect of social support in moderating the health consequences of unemployment. Journal of Health and Social Behavior, 19, 157-165.

Gunarsa, S. D. (1994). Psikologi praktis: Anak, remaja, dan keluarga. Jakarta: BPK Gunung Mulia.

Hobfoll, S. E., \& Walfisch, S. (1984). Coping with a threat to life: A longitudinal study of self-concept, social support, and psychological distress. American Journal of Community Psychology, 12, 87. 
Hoffman, M. A., Ushpiz, V., \& Levy-Shiff, R. (1988). Social support and self-esteem in adolescence. Journal of youth and adolescene, 17, 307-316. doi: 10.1007/BF01537672

Kasl, S. V. (1982). Strategies of research on economic instability and health. Psychosomatic Medicine, 17, 335-340.

Kenrick, D. T., Neuberg, S. L., \& Cialdini, R. B. (2010). Social Psychology: Goals in interaction. Boston: Pearson Education.

Kessler, R. C., Turner, J., \& House, J. S. (1988). Effects of unemployment oh health in a community survey: Main, modifying, and mediating effects. Journal of Social Issues, 44, 69-85.

Kozier, B., \& Erb, E. (1987). Fundamental nursing: Concepts and procedures (3 ed.). California: Addison-Wesley.

LaRocco, J. M., House, J. S., \& French, J. R. (1980). Social support, occupational stress, and health. Journal of Health and Social Behavior, 21, 202-218.

Linn, M. W., Sandifer, R., \& Stein, S. (1985). Effects of unemployment on mental and physical health. American Journal of Public Health, 75, 502-506.

Omrod, J. E. (2006). Educational psychology: Developing learners. NJ: Pearson/Merris Prentice Hall.

Orford, J. (1992). Community psychology: Theory and practice. New York: John Wiley and Sons.

Papu, J. (2002, Maret). Tetap percaya diri setelah PHK. Dipetik April 2003, dari e-Psikologi: http//:www.e-psikologi.com/pengembangan/010302.htm

Rice, P. L. (1987). Stress and health: Principles and practice for coping and wellness. California: Brooks and Cole Publishing.

Shavelson, R. J., \& Bolus, R. (1982). Self-concept: Interplay of theory and methods. Journal of Educational Psychology, 74, 3-17.

Sheeran, P., \& McCarty, E. (1992). Social structure, self-conception and well-being: An examination of four models with unemployed people. Journal of Applied Social Psychology, 22, 117-113.

Sheeran, P., Abrams, D., \& Orbell, S. (1995). Unemployment, self-esteem, and depression: A social comparison theory approach. Basic and Applied Social Psychology, 17, 65-82.

Steinmetz, L. L. (1979). Human relations: People and work. New York: Harper and Row.

Vinokur, A., \& Caplan, R. D. (2006). Attitudes and social support: Determinants of jobseeking behavior and well-being among unemployed. Journal of Applied Social Psychology, 17, 1007-1024. doi: 10.1111/j.1559-1816.1987.tb02345.x

Voydanoff. (1987). Work and family life. Family studies text series, No. 6. CA: Thousand Oaks. 